УДК 338.012

DOI: $10.14451 / 1.205 .314$

\title{
ИССЛЕДОВАНИЕ ПРОИЗВОДСТВА НЕМАТЕРИАЛЬНОГО КАПИТАЛА «ЗДОРОВЬЯ» В СОЦИАЛЬНО-ЭКОНОМИЧЕСКОЙ СИСТЕМЕ
}

\author{
(c) 2021 Кузнецова Алсу Мунировна \\ кандидат социологических наук, старший преподаватель кафедры управления человеческими \\ ресурсами Института управления, экономики и финансов \\ Казанский (Приволжский) федеральный университет, Россия, Казань \\ E-mail: alsu@legenda.travel
}

Исследование социально-экономических систем является первоочередной задачей на пути к устойчивому развитию. Пандемия Ковид-19 экстраполировала существующие противоречия и слабые звенья системы «экономика-экология-социальная сфера». Мировое сообщество находится в поиске проблем кризисной ситуации системы здравоохранения, переживающей фиаско и требующей компенсационных мер, грамотного регулирования и управления [5]. Автором исследования предпринята попытка создания целостной системы управления основными сферами устойчивого развития социально-экономической системы, воспроизводящей нематериальный капитал, способный оказывать регулирующее воздействие на компенсацию провалов системы здравоохранения средствами домохозяйств, что, имеет как позитивные, так и негативные последствия.

Предметом исследования является процесс производства нематериального капитала. Объектом исследование выступает механизм формирования здоровья граждан. Разработка алгоритма решения проблемы комплексного воспроизводства нематериального капитала в социально-экономической системе с учетом нестабильности, кризисных явлений пандемии Ковид-19 обуславливают теоретическую и практическую значимость исследования.

Ключевые слова: Нематериальный капитал, система здравоохранения, здоровье, устойчивое развитие, человеческий капитал, пандемия, капитал, ресурсы, социально-экономическая система.

Проанализируем механизм производства нематериального капитала социально-экономической системы через призму элементов его составляющих [4].

Первый этап исследования направлен на анализ структуры нематериального капитала в социально-экономической системе. В интересах исследования классифицируем составляющие элементы нематериального капитала по критерию общей устойчивости в условиях пандемии Ковид-19.

Таблица 1 иллюстрирует классификацию составляющих элементов нематериального капитала по признаку общей устойчивости в условиях пандемии Ковид-19.

Нематериальный капитал в исследовании предполагает совокупность нематериальных, конвертируемых в денежный эквивалент и способных симультанно приносить доход, факторов создания стоимости [2]. В контексте нашего исследования таким первоочередным фактором выступает здоровье граждан, а системообразующей структурой, этот капитал воспроизводящий, является система здравоохранения.
В настоящем исследовании были проанализирован человеческий капитал, интеллектуальный капитал, структурный капитал, репутационный капитал, социальный капитал, как составляющие совокупного нематериального производства социально-экономической системы.

Базисом нематериального производства человеческого капитала является система здравоохранения, от эффективной работы которой зависит устойчивость и эффективность всех звеньев цепи нематериального производства. Провалы рынка, как части социально-экономической системы напрямую коррелируют с фиаско сферы здравоохранения в условиях пандемии. Экстраполирует ситуацию репутационный капитал с отрицательной рентой, как антипропаганда вакцинирования в условиях пандемии. Приведём некоторые статистические данные иллюстрирующие прямую зависимость между нематериальным капиталом доверия и активностью вакцинации в мировом сообществе [4].

В выполненном исследовании лидерами вакцинации (по статистическим данным на конец 
Таблиц̧а 1. Классификация составляющих элементов нематериального капитала

\begin{tabular}{|l|l|l|l|}
\hline $\begin{array}{l}\text { Конвертационнная форма } \\
\text { нематериального капитал }\end{array}$ & $\begin{array}{l}\text { Уровень конвертационно- } \\
\text { го воздействия }\end{array}$ & $\begin{array}{l}\text { Адаптационная способ- } \\
\text { ность в условиях панде- } \\
\text { мии Ковид-19 }\end{array}$ & $\begin{array}{l}\text { Влияние фактора «здоро- } \\
\text { вье» на устойчивость вос- } \\
\text { производства капитала }\end{array}$ \\
\hline Человеческий капитал & Высокий, более $100 \%$ & Высокая & $\begin{array}{l}\text { Определяющее/прямая } \\
\text { зависимость }\end{array}$ \\
\hline $\begin{array}{l}\text { Интеллектуальный } \\
\text { капитал }\end{array}$ & Высокий, б100\% & Высокая & $\begin{array}{l}\text { Определяющее/прямая } \\
\text { зависимость }\end{array}$ \\
\hline Структурный капитал & Средний, менее $100 \%$ & Высокая & $\begin{array}{l}\text { Частичное/прямая зави- } \\
\text { симость }\end{array}$ \\
\hline Репутационный капитал & Средний, менее $100 \%$ & Средняя & $\begin{array}{l}\text { Частичное/прямая зави- } \\
\text { симость }\end{array}$ \\
\hline Социальный капитал & $\begin{array}{l}\text { Ниже среднего, менее } \\
50 \%\end{array}$ & Средняя & $\begin{array}{l}\text { Частичное/прямая зави- } \\
\text { симость }\end{array}$ \\
\hline
\end{tabular}

Источник: составлено автором по материалам исследования

2021 года) являются страны с благоприятной социально-экономической ситуацией и высокой лояльностью к деятельности правительства, государственных структур, системы здравоохранения.

Анализ статистических данных иллюстрирует ситуацию вакцинации в некоторых странах глобального сообщества. Пандемия Ковид-19 объединила страны с различным уровнем и качеством жизни, развитостью системы интернет и системы здравоохранения в решении первоочередной задачи для всего мирового сообщества - победы над вирусными заболеваниями, создавшими новую реальность и условия хозяйствования, передвижения, торговли, жизнедеятельности. Только объединив усилия, конкурентные преимущества различных социально-экономических систем возможна эффективная нейтрализация негативных последствий пандемии Ковид-19 в современных условиях. Сегодня становится очевидной необходимость адаптационных изменений системы здравоохранения как ключевой в область разворота к устойчивому развитию.

При всех негативных последствиях пандемии Ковид-19 численность населения планеты продолжает увеличиваться и приближается к восьми миллиардам. Следовательно, кризис системы здравоохранения имеет социально-экономическую природу, а не экологическую, в строгом смысле [5].

Вторым этапом исследования является выявление системных взаимосвязей и взаимозависимостей факторов нематериального капитала здоровья. Выявляя причинно-следственную цепочку производства фактора «здоровье» бу- дем ориентироваться правилом логики: направление исследования «от причин к следствиям, а не от следствий к причинам» того или иного события. Данный методологический подход позволяет превентивно отклонять неэффективные схемы исследования, оставляя пространство для новых взглядов на существующую ситуацию с пандемией Ковид-19, которую не мог спрогнозировать ни один ученый, несмотря на очевидную спиралеобразность развития истории.

Третьим этапом исследования является распределение зон ответственности между секторами «домохозяйство» - «государство» за уровень и качество воспроизводства капитала «здоровья в социально-экономической системе». Отдельно также следует выделить социальную ответственность бизнеса, не лишенную противоречий в области нормативно-правового регулирования и стандартизации в области устойчивого развития, как совокупности экономической, экологической и социальных сфер устойчивого воспроизводства нематериального капитала «здоровья» [3].

Таблица 2 содержит результаты анализа классификационных групп ответственности за воспроизводство нематериального капитала «здоровья».

Разработанная авторам трехэтапная структура анализа воспроизводства нематериального капитала здоровья в социально-экономической системе является дополнением к уже существующей системе управления устойчивым развитием [1]. Выявленные и классифицированные по структурным признакам сферы ответственности позволяют управлять воспроизводством нематериального капитала «здоровья» в расши- 
Таблица 2. Классификационная группа ответственности за воспроизводство нематериального капитала «здоровья»

\begin{tabular}{|c|c|c|}
\hline $\begin{array}{l}\text { Классификацион- } \\
\text { ная группа ответ- } \\
\text { ственности }\end{array}$ & $\begin{array}{l}\text { Показатели, определяющие ответствен- } \\
\text { ность группы }\end{array}$ & Угрозы/возможности \\
\hline $\begin{array}{l}\text { Ответственность } \\
\text { государства }\end{array}$ & $\begin{array}{l}\text { - уровень заболеваний, имеющих не- } \\
\text { системную качество профессионального } \\
\text { образование в системе здравоохранения; } \\
\text { численность персонала сферы здравоохра- } \\
\text { нения; }\end{array}$ & $\begin{array}{l}\text { - угроза пандемии/возможность вос- } \\
\text { производства нематериального капитала } \\
\text { «доровья»; } \\
\text { - Угроза снижения качества и уровня жиз- } \\
\text { ни/возможность управления качеством, } \\
\text { уровнем жизни; } \\
\text { - Угроза нивелирования профессиона- } \\
\text { лизма работников сферы здравоохране- } \\
\text { ния/возможность управления качеством } \\
\text { сферы здравоохранения. }\end{array}$ \\
\hline $\begin{array}{l}\text { Ответственность } \\
\text { домохозяйств }\end{array}$ & $\begin{array}{l}\text { - Выполнение предписаний и рекоменда- } \\
\text { ций системы здравоохранения и государ- } \\
\text { ственных регулирующих органов; }\end{array}$ & $\begin{array}{l}\text { - Угроза распространения негативных } \\
\text { последствий пандемии; } \\
\text { - Возможность ответственного воспроиз- } \\
\text { водства нематериального капала «здоро- } \\
\text { вье» в социально-экономической системе. }\end{array}$ \\
\hline $\begin{array}{l}\text { Социальная } \\
\text { ответственность } \\
\text { бизнеса }\end{array}$ & $\begin{array}{l}\text { - Ведение бизнеса в соответствии тре- } \\
\text { бованиями и постулатами устойчивого } \\
\text { развития. }\end{array}$ & $\begin{array}{l}\text { - Угроза нарушения стандартов и ини- } \\
\text { циатив в области устойчивого развития } \\
\text { бизнеса. } \\
\text { - Возможность повышения ответственно- } \\
\text { сти бизнеса с учетом требований устойчи- } \\
\text { вого развития. }\end{array}$ \\
\hline
\end{tabular}

Источник: составлено авторами по материалам исследования

ренном объеме с учетом изменчивости и агрессивности внешней среды пандемии Ковид-19.

Таким образом, автором выполнено исследование производства нематериального капитала «здоровья» в социально-экономической системе, составлена классификационная группа ответственности за воспроизводство нематериального капитала «здоровья», позволяющая более точно оценить угрозы и возможности последствий пандемии, разработать эффективную систему управления взаимосвязанной системой «домохозяйства-государство-бизнес». Предпринятая автором попытка создания целостной системы управления основными сферами устойчивого развития социально-экономической системы, путем реализации трехэтапного исследования капитала «здоровья» вносит существенный вклад в методологию исследования нематериального капитала.

\section{Библиографический список}

1. Колесникова Ю.С., Фахрутдинова Е.В., Юрков Д.В. Привлечение и удержание высококвалифицированных специалистов в Республику Татарстан//Экономические науки, 2020, №12 (193), с. 246-250

2. Сафиуллин М.Р., Ельшин Л.А., Фахрутдинова Е.В. /Эффективность развития региональной высшей школы: качественно-количественный анализ (на примере Приволжского федерального округа)/Вестник высшей школы. - 2019. -№ 12. -с. 55-61.

3. Фахрутдинова Е.В., Камашева А.В., Валеев Э.Р. Статистический анализ дифференциации субъектов Российской Федерации по качеству жизни населения// Экономические науки. - 2019. -№ 12. - С. 356-362

4. Фахрутдинова Е.В., Грудина С.И. Индекс доверия как фактор устойчивости воспроизводства нематериального капитала региона/Е.В. Фахрутдинова, С.И. Грудина// Казанский экономический вестник. - 2021. № $5 .-$ C. 35-40.

5. Global Intangible Finance Tracker $\left(\mathrm{GIFT}^{\mathrm{TM}}\right) / \mathrm{an}$ annual review of the world»s intangible value/November 2019/[Электронный ресурс https://brandfinance.com/wp-content/uploads/1/gift_2.pdf 